So far only isolated specimens from the Red Sea volcanic islands have received preliminary examination under the microscope. All the specimens examined were olivine basalts, but there is considerable textural variation from strongly porphyritic to aphyric types but with a relatively uniform mineral content. The main rock-forming minerals are olivine $\left(c . \mathrm{Fa}_{12-20}\right)$, clinopyroxene and plagioclase (c. $\left.A n_{50-65}\right)$. When present as phenocrysts, the olivine is euhedral and commonly zoned from a forsteritic core to a more fayalitic margin, while plagioclase phenocrysts, although within the labradorite range, are often progressively zoned from a calcic core to a more sodic rim. The ground mass is intergranular with minute, sub-hedral crystals of olivine and clinopyroxene occurring between laths of plagioclase. Volcanic glass, or its alteration products, is rare. Sufficient work has not been undertaken to establish whether there is any significant petrological variation between the rocks of the three island groups, but specimens examined indicate affinities with the alkaline rather than the tholeiitic association.

Petrographic investigation of the specimens collected in all areas is in progress at present.
We thank the chairman and members of the Volcano. logical Expeditions Committee of the Royal Society for their support and encouragement and the Royal Society and the Universities of Leeds and Edinburgh for financial assistance. We also thank the various branches of H.M. Forces for their assistance and hospitality during our stay in South Arabia, and members of the British Petroleum Company, Aden and Little Aden, and the South Arabian Federal Government for their generous assistance.

2 Vellain, C., Bull. Geol. Soc. France, Ser. 3, 5, 146 (1877).

${ }^{2}$ McMahon, C. A., Rec. Geol. Surv. India, 16, 145 (1883).

${ }^{3}$ Raisin, C. A., Geol. Mag., 9, 132 and 206 (1902),

- Prior, G. T., Miner. Mag., 8, 228 (1903).

'Bler, F., Denkschriften der Kaiserlichen Akademie der Wissenschaften, Mathematisch-Naturwissenschuftliche Klasse, Bd. 71, 1 (1907).

- Manasse, E., Mem. (Atti.) Soc. Tosc. Sci. Nat., 25, 153 (1908).

7 Vredenburg, E. W., Rec. Geol. Surv. India, 38, 321 (1910).

${ }^{3}$ Teilhard de Chardin, P., et al., Mem. Geol. Soc. France, 14 (1930).

- MacFadyen, W. A., Geol. Mag. 69, 63 (1932).

${ }^{10}$ Wissman, H., Rathjens, C., and Kossmatt, F., Geol. Rundsch., 33 (1942).

${ }^{21}$ Shukri, N. M., and Basta, E. Z., Bull. Fac. Sci. Cairo Univ., 35, 87 (1959).

${ }^{12}$ Irving, E., and Tarling, D. H., H. Geophys. Res., 66, 549 (1960).

${ }^{13}$ Ann. Rep. Res. Inst. African Geol., Leeds Univ., 1961-62 (1963).

" Mohr, P. A., The Geology of Ethiopia (Univ. Coll. Addis Ababa Press, 1964).

\title{
OBITUARIES
}

\section{Prof. Hans Halban}

Prof. Hans Halban, who died on November 28, 1964, at the age of fifty-six, will be widely remembered among scientists for his major contributions in slow neutron physics before the Second World War which led up to the successful realization of the nuclear reactor.

Halban was born in Leipzig on January 26, 1908, and after education in Austria ho went to the University of Zurich, where he gained his Ph.D. in 1935, working in the laboratory where his father was professor of physical chemistry. He then moved to Mme Curie's Institut de Radium in Paris, and it was at this time that he started his research on slow neutron physics. In 1937 he went with a special scholarship to Niels Bohr's laboratory in Copen. hagen and carried out neutron experiments with Frisch and Koch, which included a measurement of the neutron magnetic moment and a study of the internal field in a ferromagnetic substance using neutrons. He returned to Paris in 1938 to become Chargé de Recherches in the Laboratoire de Chimie Nucleaire in the Collège de France of which F. Joliot-Curie was director and where he continued his neutron studies. This culminated in his great work in 1939 along with Kowarski and Joliot-Curio on the neutrons from the fission of uranium. It was these experiments involving the moderation of neutrons in uranium solutions that first demonstrated the possibility of a chain reaction and, in a classic sequence of papers in that year, Halban, Kowarski and Joliot-Curie discussed the process together with methods for its control. This work was interrupted by the War and the fall of France in 1940, but Halban succeeded in escaping to England, bringing with him under dramatic circumstances the procious churns of heavy water. These 180 litres formed the greater part of the world's stock and had been purchased to extend the moderation studies in Paris. Under the auspices of the MAUD Committee this research was continued in the Cavendish Laboratory where Halban was in charge of the slow neutron team. As the effort on the project developed, so the active centre of research moved to Montreal and in 1942 he took charge of the joint British-Canadian team which included several distin. guished French scientists and was concerned, among other matters, with the development of reactors. It was this work which finally led to the construction of the heavywater reactor at the Chalk River Laboratories.

$\mathrm{He}$ resigned this appointment in 1945 and a year later went to Oxford at the invitation of Lord Cherwell, who was then head of the Clarendon Laboratory. He quickly built up a team of research students which was set to work on problems both in neutron and nuclear structure physics. Many of these research students came from overseas and had been drawn to him through his wide contacts abroad and his international reputation as a physicist. Under his lively and imaginative influence the group flourished and produced many original papers on a wide range of subjects. The research was often hampered by shortage of funds and equipment, and with characteristic generosity he would contribute from his own resources to enable the work to continue. It was in 1951 that a cooperative effort betweon some of his nuclear physics group and a number of low-temperature physicists under the general direction of the late Sir Francis Simon showed that it was possible to attain a substantial degree of alignment of the nuclei of radioactive cobalt-60. This field of research, in which he had first become interested in 1937, soon developed into a powerful tool for studying problems in both nuclear and solid-state physies and is being actively pursued to this day in many laboratories. In 1950 he was made a fellow of St. Antony's College in whose foundation he was deeply interested, and in 1954 the University of Oxford conferred the title of professor on him. He returned to Paris in 1956 to become professeur associé at the Ecole Normale Supérieure and a director of the Orsay laboratory, where a high-energy electron accelerator was to be installed. He retired from active nuclear physies in 1963.

Halban will be remembered by his friends and colleagues, and not least by his research students, for his boundless enthusiasm, his originality and his continuous stream of ideas. He was critical of his own work and he demanded a high standard from others, but he tempered this with great understanding, generosity, warmth and loyalty. He was a dynamic character and a great physicist.

\section{A. Gra Gr}

\section{Prof. A. Voisin}

AN internationally recognized figure, Prof. André Voisin died in Cuba on December 22, 1964, at the age of sixty-one, while engaged on a lecturing programme connected with the reorganization of the agriculture of that country.

The study of grassland and the grazing animal, by virtue of its complexity, has given rise over the years to many prophets: men of zeal, evangelistic by nature, and 